\title{
PF1270A, B and C, Novel Histamine H3 Receptor Ligands Produced by Penicillium waksmanii PF1270
}

\author{
Nobuaki Kushida, Naoko Watanabe, Takako Okuda, Fumikazu Yokoyama, \\ Yasuhiro Gyobu, Takashi Yaguchi
}

Received: July 30, 2007 / Accepted: October 2, 2007

(C) Japan Antibiotics Research Association

\begin{abstract}
Three novel histamine $\mathrm{H} 3$ receptor $(\mathrm{H} 3 \mathrm{R})$ ligands, PF1270A (1), PF1270B (2) and PF1270C (3) were isolated from the culture broth of the fungal strain PF1270. The strain was identified as Penicillium waksmanii on the basis of morphological characteristics. These compounds were obtained from the culture broth by solvent extraction and chromatographic purification. Their structures were established by spectroscopic methods and $\mathrm{X}$-ray crystallographic analysis. They possess pentacyclic spiroindolinone skeletons. 1, 2 and $\mathbf{3}$ displayed high affinity for the rat H3R ( $K i=0.058,0.17$ and $0.19 \mu \mathrm{M}$, respectively) and human H3R ( $K i=0.047,0.12$ and $0.22 \mu \mathrm{M}$, respectively). Moreover, 1, $\mathbf{2}$ and $\mathbf{3}$ acted as potent agonists with the $\mathrm{EC}_{50}$ values of $0.12,0.15$ and $0.20 \mu \mathrm{M}$, respectively.
\end{abstract}

Keywords histamine $\mathrm{H} 3$ receptor ligand, Penicillium waksmanii, PF1270A, PF1270B, PF1270C

\section{Introduction}

Histamine is one of the biological amines broadly distributed in various mammalian tissues. Its pharmacological activities are transferred into cells via histamine receptors existing on the cell membrane. Histamine H1, H2, H3 and H4 receptors have been reported as isoforms of histamine receptors [1 4].
Histamine $\mathrm{H} 3$ receptors (H3Rs) that are distributed in the brain and peripheral tissues were identified pharmacologically in 1983 by Arrang et al. [3]. H3Rs regulate synthesis and release of histamine as autoreceptors $[5,6]$. Further, they play roles as heteroreceptors that control the release of various neurotransmitters such as serotonin, noradrenalin and dopamine in the brain [7 9]. Therefore, H3R ligands are potential therapeutic agents for diabetes, obesity, and central nervous system (CNS) disorders such as attention-deficit hyperactivity disorder (ADHD), cognitive disorders, depression, epilepsy and sleep disorders [10 13].

In this paper, we describe the taxonomy and fermentation of the strain PF1270, the isolation, physico-chemical properties, structure elucidation and biological activities of the novel H3R ligands, PF1270A (1), PF1270B (2) and PF1270C (3) (Fig. 1).

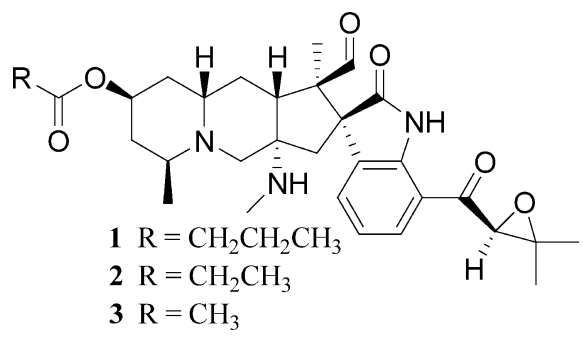

Fig. 1 Structures of PF1270A (1), B (2) and C (3).
N. Kushida (Corresponding author), N. Watanabe: Pharmaceutical Research Center, Meiji Seika Kaisha, Ltd., 760 Morooka-cho, Kohoku-ku, Yokohama 222-8567, Japan,

E-mail: nobuaki_kushida@meiji.co.jp

T. Okuda: Clinical Research, Meiji Seika Kaisha, Ltd., 4-16 Kyobashi 2-chome, Chuo-ku, Tokyo 104-8002, Japan
F. Yokoyama, Y. Gyobu: Bioscience Laboratories, Meiji Seika Kaisha, Ltd., 788 Kayama, Odawara 250-0852, Japan

T. Yaguchi: Medical Mycology Research Center, Chiba University, 1-8-1 Inohana, Chuo-ku, Chiba 260-8673, Japan 


\section{Materials and Methods}

\section{General}

FAB-MS and HR-FAB-MS were measured with a JEOL JMS-FABmate mass spectrometer and a JEOL JMS-700 mass spectrometer, respectively. UV and IR spectra were recorded with a Shimadzu UV-260 spectrometer and a Shimadzu FTIR-8100 spectrometer, respectively. Optical rotations were obtained with a JASCO DIP-370 digital polarimeter using a $10 \mathrm{~cm}$ cell. Melting points were determined with a Yanaco MP-J3 micro melting point apparatus. NMR spectra were measured with a JEOL JNMLA400 spectrometer. X-ray diffraction measurement was performed on a Rigaku AFC7R diffractometer with graphite monochromated $\mathrm{Cu}-\mathrm{K} \alpha$ radiation and rotating anode generator.

\section{Microorganism}

The fungal strain PF1270 was isolated from a soil sample collected in Shimane Prefecture, Japan. The strain has been deposited at the International Patent Organism Depositary, the National Institute of Advanced Industrial Science and Technology, Japan under the accession number FERM BP08610 .

\section{Taxonomy}

Taxonomic studies of the strain PF1270 were performed according to the methods of Pitt [14]. For the evaluation of culture characteristics, Czapek's yeast extract agar (CYA, $\mathrm{K}_{2} \mathrm{HPO}_{4} 0.1 \%$, yeast extract $0.5 \%$, sucrose $3.0 \%, \mathrm{NaNO}_{3}$ $0.3 \%, \mathrm{KCl} 0.05 \%, \mathrm{MgSO}_{4} \cdot 7 \mathrm{H}_{2} \mathrm{O} 0.05 \%, \mathrm{FeSO}_{4} \cdot 7 \mathrm{H}_{2} \mathrm{O}$ $0.001 \%$, agar $1.5 \%$ ) and malt extract agar (MEA, malt extract $2.0 \%$, peptone $0.1 \%$, glucose $2.0 \%$, agar $1.5 \%$ ) were used. The color was identified in accordance with the Methuen Handbook of Colour [15]. Morphology was observed under an optical microscope.

\section{Fermentation}

A slant culture of the strain PF1270 was used to inoculate fifteen $100-\mathrm{ml}$ Erlenmeyer flasks. Each contained $20 \mathrm{ml}$ of a seed medium consisting of glucose $1.0 \%$, soluble starch $2.0 \%$, yeast extract $0.3 \%$, polypeptone $0.5 \%$, soybean meal $0.2 \%$, wheat germ $0.6 \%$ and $\mathrm{CaCO}_{3} 0.2 \%$ in deionized water adjusted to $\mathrm{pH} 7.0$ with $\mathrm{NaOH}$ solution prior to sterilization. The flasks were incubated at $25^{\circ} \mathrm{C}$ for 72 hours on a rotary shaker at $220 \mathrm{rpm}$. Portions of $3.0 \mathrm{ml}$ of this seed culture were transferred into one hundred $500-\mathrm{ml}$ Erlenmeyer flasks, each of which contained soybean meal $2.5 \%$ and water-absorbed rice $100 \mathrm{~g}$ as solid production medium. The flasks were thoroughly stirred and then statically cultured at $25^{\circ} \mathrm{C}$ for 14 days. After incubation, $10 \mathrm{~kg}$ portion of the obtained culture was extracted with 20 liters of $67 \%$ aqueous acetone.

\section{Cell Culture}

CHO cells stably expressing recombinant human H3Rs prepared by Meiji Seika Kaisha, Ltd. were cultured in Dulbecco's modified Eagle's medium supplemented with $10 \%$ fetal calf serum, $50 \mathrm{U} / \mathrm{ml}$ penicillin, $50 \mu \mathrm{g} / \mathrm{ml}$ streptomycin and $1.0 \mathrm{mg} / \mathrm{ml} \mathrm{G} 418$ at $37^{\circ} \mathrm{C}$ in $5.0 \% \mathrm{CO}_{2}$.

\section{Membrane Preparation of rat H3Rs}

Forebrain from a Sprague-Dawley (SD) rat was homogenized at $4^{\circ} \mathrm{C}$ in 10 volumes of $0.32 \mathrm{M}$ sucrose solution in a Teflon-glass homogenizer. The homogenate was centrifuged at $1,500 \times g$ for 10 minutes. The supernatant was further centrifuged at $40,000 \times g$ for 20 minutes at $4^{\circ} \mathrm{C}$. The pellets were suspended in 10 volumes of buffer $(50 \mathrm{mM}$ Tris- $\mathrm{HCl}$, $\mathrm{pH} 7.4,5.0 \mathrm{mM}$ EDTA) and centrifuged under the abovementioned conditions. This step was repeated and the resulting membranes were stored at $-80^{\circ} \mathrm{C}$.

\section{Cell Membrane Preparation of Human H3Rs}

$\mathrm{CHO}$ cells stably expressing recombinant human H3Rs were harvested and centrifuged at $1,500 \times g$ for 5 minutes at $4{ }^{\circ} \mathrm{C}$. The pellets were suspended in 10 volumes of $50 \mathrm{mM}$ Tris- $\mathrm{HCl}$ buffer, $\mathrm{pH} 7.4$ and homogenized by sonication (Sonifier, Branson), which was then centrifuged at $40,000 \times g$ for 20 minutes at $4^{\circ} \mathrm{C}$. This step was repeated and the resulting cell membranes were stored at $-80^{\circ} \mathrm{C}$.

\section{Ligand Binding Assay}

Membranes expressing rat H3Rs $(225 \mu \mathrm{g} / \mathrm{ml})$ or recombinant human H3Rs $(25 \mu \mathrm{g} / \mathrm{ml})$ were incubated in $200 \mu \mathrm{l}$ of Tris-assay buffer ( $50 \mathrm{mM}$ Tris- $\mathrm{HCl}, \mathrm{pH} 7.4,5.0 \mathrm{mM}$ EDTA) on the 96 -well plate. $1.0 \mathrm{nM} N-\alpha$-[methyl- $\left.{ }^{3} \mathrm{H}\right]-$ histamine dihydrochloride $(3.0 \mathrm{TBq} / \mathrm{mmol}$, PerkinElmer $)$ and various concentrations of compounds were added to the buffer. Non-specific binding was determined with $10 \mu \mathrm{M}$ thioperamide (Tocris). The samples were incubated for 60 minutes at room temperature. The reaction was stopped by rapid filtration through 96-well microplate, (UniFilter $\mathrm{GF} / \mathrm{B}$, PerkinElmer) soaked in polyethyleneimine $(0.3 \%)$ using a cell harvester (FilterMate, PerkinElmer). Filters were washed five times with Tris-assay buffer and dried for 60 minutes at $50^{\circ} \mathrm{C}$. Then, $30 \mu \mathrm{l}$ of MicroScinti20 (PerkinElmer) was dispensed to each well. The radioactivity was measured by a liquid scintillation counter (TopCount96, PerkinElmer). The $K i$ values were calculated from $\mathrm{IC}_{50}$ values according to the Cheng-Prusoff equation. 


\section{$\left[{ }^{35} \mathrm{~S}\right]$ GTP $\gamma$ S Binding Assay}

Cell membranes expressing recombinant human H3Rs $(10 \mu \mathrm{g} / \mathrm{ml})$ were incubated in $250 \mu \mathrm{l}$ of assay buffer (50 mM Tris- $\mathrm{HCl}, \mathrm{pH} 7.4,100 \mathrm{mM} \mathrm{NaCl}, 3.0 \mathrm{mM} \mathrm{MgCl}_{2}$, $0.2 \mathrm{M}$ EGTA, $1.0 \mathrm{mM}$ DTT) on the 96 -well plate. $200 \mathrm{pM}$ guanosine $5^{\prime}\left[\gamma_{-}{ }^{35} \mathrm{~S}\right]$ thiotriphosphate, triethylamine salt (38 TBq/mmol, GE Healthcare), $10 \mu \mathrm{M}$ GDP (SigmaAldrich) and various concentrations of compounds were added to the buffer with or without $10 \mathrm{nM}(R)-(-)-\alpha-$ methylhistamine (Tocris) as an antagonist format or as an agonist format. The samples were incubated for 60 minutes at room temperature. The reaction was stopped by rapid filtration through 96-well microplate, (UniFilter GF/B, PerkinElmer) using a cell harvester (FilterMate, PerkinElmer). Filters were washed eight times with wash buffer ( $50 \mathrm{mM}$ Tris- $\mathrm{HCl}, \mathrm{pH} 7.4,3.0 \mathrm{mM} \mathrm{MgCl}$ ) and dried for 60 minutes at $50^{\circ} \mathrm{C}$. Then, $30 \mu 1$ of MicroScinti-20 (PerkinElmer) was dispensed to each well. The radioactivity was measured by a liquid scintillation counter (TopCount96, PerkinElmer). Agonistic activity was calculated as follows: Agonistic activity $(\%$ effect $)=($ radioactivity with tested sample) $/($ radioactivity without tested sample $) \times 100 . \mathrm{EC}_{50}$ values were calculated from a sigmoid curve of agonistic activities.

\section{Results}

\section{Taxonomy}

The cultural characteristics of the strain PF1270, grown at $25^{\circ} \mathrm{C}$ for 14 days, were as follows. Colonies on CYA reached $18 \sim 26 \mathrm{~mm}$ in diameter and produced abundant conidiogenesis. The colony surface was velvety, plane and grayish green. The reverse was dense yellow. Colonies on MEA reached $17 \sim 19 \mathrm{~mm}$ in diameter and produced abundant conidiogenesis. The colony surface was velvety, plane and grayish green. The reverse was dense yellow. The strain PF1270 did not grow on either medium at $37^{\circ} \mathrm{C}$.

Morphological characteristics of the strain PF1270 were as follows. Conidiophores were borne from the substrate and aerial hyphae, and penicilli were monoverticillate or biverticillate. Phialides were ampulliform and $6 \sim 8 \times$ $1.5 \sim 2 \mu \mathrm{m}$. Conidia were globose to subglobose, smooth, $2 \sim 3 \mu \mathrm{m}$ and borne in long chains (Fig. 2). Based on the above characteristics, the strain PF1270 was identified as Penicillium waksmanii.

\section{Isolation}

The culture broth was extracted with 20 liters of $67 \%$ aqueous acetone. The filtrate of the extracts was concentrated in vacuo to remove acetone and adjusted to

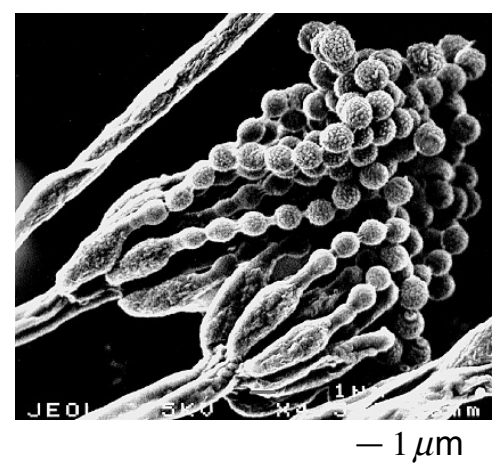

Fig. 2 Scanning electron micrograph of strain PF1270.

pH 7.0 with $1 \mathrm{~N} \mathrm{NaOH}$ solution. The aqueous solution was adsorbed onto a column of DIAION HP-20 (Mitsubishi Chemical Corporation). The column was successively washed with 3.0 liters of water and 3.0 liters of $50 \%$ aqueous acetone, and then eluated with 3.0 liters of acetone. To this acetone eluate was added 3.0 liters of water and the mixture concentrated under reduced pressure. The resulting aqueous solution was adjusted to $\mathrm{pH} 9.0$ with $1 \mathrm{~N}$ $\mathrm{NaOH}$ solution and extracted with an equal volume of ethyl acetate. Evaporation of the ethyl acetate layer gave $3.7 \mathrm{~g}$ of a crude extract which was subjected to a silica gel column chromatography (Wako Gel C-300, Wako Pure Chemical Industries) with stepwise elution using hexane-ethyl acetate $(90: 10,50: 50,30: 70$ and neat ethyl acetate). The combined active fractions were concentrated in vacuo. The residue was applied onto a column of silica gel and eluted stepwise with hexane - ethyl acetate $(90: 10,80: 20,70: 30$, $60: 40,50: 50,40: 60$ and $30: 70$ ). The active fractions were collected and concentrated in vacuo. The residue was subjected to a silica gel column chromatography and eluted with chloroform - methanol $(50: 1)$. The active fractions were combined and concentrated in vacuo to give a small volume of methanol-soluble crude extract containing $\mathbf{1}$ and precipitates containing $\mathbf{1 , 2}$ and $\mathbf{3}$. The methanol-soluble crude extract was purified by six preparative TLCs (Silica gel $60 \mathrm{~F}_{254}, 0.5 \mathrm{~mm}$, Merck) with hexane - ethyl acetate ( $1: 10)$ to give $72.3 \mathrm{mg}$ of $\mathbf{1}$ as a yellowish white powder. The precipitates containing $\mathbf{1}, \mathbf{2}$ and $\mathbf{3}$ were purified by preparative HPLC (Inertsil ODS-2, $20 \mathrm{~mm}$ i.d. $\times 250 \mathrm{~mm}$, GL Science, acetonitrile $/ 0.005 \%$ phosphoric acid $=22: 78$ ) to give $70.2 \mathrm{mg}$ of $\mathbf{1}$, the residue containing $\mathbf{2}$ and the residue containing $\mathbf{3}$. The residue containing 2 was further purified by a preparative TLC (Silica gel $60 \mathrm{~F}_{254}, 0.5 \mathrm{~mm}$, Merck) with hexane - ethyl acetate $(1: 5)$ to give $17.0 \mathrm{mg}$ of $\mathbf{2}$ as a yellowish white powder. The residue containing $\mathbf{3}$, upon a preparative TLC (Silica gel $60 \mathrm{~F}_{254}, 0.5 \mathrm{~mm}$, Merck) with hexane - ethyl acetate $(1: 5)$, gave $6.0 \mathrm{mg}$ of $\mathbf{3}$ as a 
Table 1 Physico-chemical properties of PF1270A (1), PF1270B (2) and PF1270C (3)

\begin{tabular}{|c|c|c|c|}
\hline & 1 & 2 & 3 \\
\hline Appearance & Yellowish white powder & Yellowish white powder & Yellowish white powder \\
\hline Molecular formula & $\mathrm{C}_{32} \mathrm{H}_{43} \mathrm{~N}_{3} \mathrm{O}_{6}$ & $\mathrm{C}_{31} \mathrm{H}_{41} \mathrm{~N}_{3} \mathrm{O}_{6}$ & $\mathrm{C}_{30} \mathrm{H}_{39} \mathrm{~N}_{3} \mathrm{O}_{6}$ \\
\hline FAB-MS $(m / z)$ & $566(\mathrm{M}+\mathrm{H})^{+}$ & $552(\mathrm{M}+\mathrm{H})^{+}$ & $538(\mathrm{M}+\mathrm{H})^{+}$ \\
\hline \multicolumn{4}{|l|}{ HR-FAB-MS (m/z) } \\
\hline Found & $566.3224(\mathrm{M}+\mathrm{H})^{+}$ & $552.3077(\mathrm{M}+\mathrm{H})^{+}$ & $538.2917(\mathrm{M}+\mathrm{H})^{+}$ \\
\hline Calcd. & 566.3230 (for $\mathrm{C}_{32} \mathrm{H}_{44} \mathrm{~N}_{3} \mathrm{O}_{6}$ ) & 552.3073 (for $\mathrm{C}_{31} \mathrm{H}_{42} \mathrm{~N}_{3} \mathrm{O}_{6}$ ) & 538.2917 (for $\mathrm{C}_{30} \mathrm{H}_{40} \mathrm{~N}_{3} \mathrm{O}_{6}$ ) \\
\hline$[\alpha]_{D}^{25}\left(c 1.0, \mathrm{CH}_{3} \mathrm{CN}\right)$ & $+75.0^{\circ}$ & $+82.8^{\circ}$ & $+79.6^{\circ}$ \\
\hline$U V \lambda_{\max }^{\mathrm{CH}_{3} \mathrm{CN}} \mathrm{nm}(\varepsilon)$ & $\begin{array}{l}202(25200), 228 \text { (18800), } \\
246(24600), 334(9030)\end{array}$ & $\begin{array}{l}201(23800), 228 \text { (17200), } \\
246(22400), 334(8110)\end{array}$ & $\begin{array}{l}199(20700), 228 \text { (13300), } \\
247(17700), 334 \text { (6380) }\end{array}$ \\
\hline $\mathrm{IR} v_{\max }(\mathrm{KBr}) \mathrm{cm}^{-1}$ & $\begin{array}{l}3384,2934,1721,1674 \\
1601,1445,1381,1254 \\
1184,1090,1069,764\end{array}$ & $\begin{array}{l}3411,2942,1728,1673 \\
1603,1450,1381,1255 \\
1188,1092,1069,762\end{array}$ & $\begin{array}{l}3382,2964,1732,1676 \\
1605,1453,1381,1250 \\
1190,1103,1069,758\end{array}$ \\
\hline Melting point & $173 \sim 175^{\circ} \mathrm{C}$ & $176 \sim 178^{\circ} \mathrm{C}$ & $187 \sim 189^{\circ} \mathrm{C}$ \\
\hline \multicolumn{4}{|l|}{ Solubility } \\
\hline soluble & $\begin{array}{l}\mathrm{CHCl}_{3}, \mathrm{MeOH}, \text { Acetone, } \\
\mathrm{CH}_{3} \mathrm{CN}, \mathrm{EtOAc} \text { DMSO }\end{array}$ & $\begin{array}{l}\mathrm{CHCl}_{3}, \mathrm{MeOH}, \text { Acetone, } \\
\mathrm{CH}_{3} \mathrm{CN}, \mathrm{EtOAc} \text { DMSO }\end{array}$ & $\begin{array}{l}\mathrm{CHCl}_{3}, \mathrm{MeOH}, \text { Acetone, } \\
\mathrm{CH}_{3} \mathrm{CN}, \mathrm{EtOAc} \text { DMSO }\end{array}$ \\
\hline insoluble & Hexane, $\mathrm{H}_{2} \mathrm{O}$ & Hexane, $\mathrm{H}_{2} \mathrm{O}$ & Hexane, $\mathrm{H}_{2} \mathrm{O}$ \\
\hline
\end{tabular}

yellowish white powder.

1 was recrystallized from acetone $-\mathrm{H}_{2} \mathrm{O}$ for $\mathrm{X}$-ray crystallographic analysis.

\section{Physico-chemical Properties}

The physico-chemical properties of $\mathbf{1}, \mathbf{2}$ and $\mathbf{3}$ are summarized in Table 1. These data suggest that they are structurally related. The ${ }^{1} \mathrm{H}$ - and ${ }^{13} \mathrm{C}$-NMR spectral data of $\mathbf{1}, \mathbf{2}$ and $\mathbf{3}$ observed in $\mathrm{CDCl}_{3}$ are summarized in Table 2.

\section{Structure Elucidation}

The molecular formula of $\mathbf{1}$ was established as $\mathrm{C}_{32} \mathrm{H}_{43} \mathrm{~N}_{3} \mathrm{O}_{6}$ by HR-FAB-MS. The ${ }^{1} \mathrm{H}-\mathrm{NMR}$ spectrum data of $\mathbf{1}$ showed one aldehyde proton signal at $\mathrm{H}-29(\delta$ 9.64) and three arotamic proton signals at $\mathrm{H}-4(\delta 7.94), \mathrm{H}-5(\delta 7.16)$ and H-6 $\left(\delta\right.$ 7.76). The ${ }^{13} \mathrm{C}-\mathrm{NMR}$ and HSQC spectra showed 32 carbon atoms (six methyl, seven methylene, nine methine and ten quaternary carbons). The ${ }^{1} \mathrm{H}-{ }^{1} \mathrm{H}$ COSY and HMBC correlations of $\mathbf{1}$ are summarized in Fig. 3. In the ${ }^{1} \mathrm{H}-{ }^{1} \mathrm{H}$ COSY spectrum, sequential proton networks were observed from $\mathrm{H}-27$ to $\mathrm{H}-18$, from $\mathrm{H}-2^{\prime}$ to $\mathrm{H}-4^{\prime}$ and from $\mathrm{H}-4$ to $\mathrm{H}-$ 6 . In the $\mathrm{HMBC}$ spectrum, cross peaks were observed from NH-1 to C-3, C-3a and C-7a, from H-4 to C-6 and C-7a, from $\mathrm{H}-5$ to $\mathrm{C}-3 \mathrm{a}$ and $\mathrm{C}-7$ and from $\mathrm{H}-6$ to $\mathrm{C}-4$ and $\mathrm{C}-7 \mathrm{a}$, respectively. These correlations indicated the connectivity of an indolinone ring (from NH-1 to C-7a). Cross peaks were also observed from $\mathrm{H}-8$ to $\mathrm{C}-2, \mathrm{C}-3, \mathrm{C}-3 \mathrm{a}, \mathrm{C}-9, \mathrm{C}-10$, C-18 and C-19, from H-10 to C-9, C-16 and C-18, respectively. These correlations revealed the connectivity between dodecahydrocyclopenta $[b]$ quinolizine $(\mathrm{N}-11, \mathrm{C}-3$ and from $\mathrm{C}-8$ to $\mathrm{C}-19$ ) and the indolinone ring through the spiro carbon (C-3). Cross peaks were observed from H-26 to $\mathrm{C}-9$, from $\mathrm{H}-28$ to $\mathrm{C}-3, \mathrm{C}-18, \mathrm{C}-19$ and $\mathrm{C}-29$ and from $\mathrm{H}-29$ to $\mathrm{C}-19$. These correlations and the carbon chemical shift of C-26 suggested the connectivity from C-26 to C-9 through NH-25 and from C-28 and C-29 to C-19, respectively. Cross peaks were observed from $\mathrm{H}-6$ to C-20, from $\mathrm{H}-21$ to $\mathrm{C}-20$ and $\mathrm{C}-22$, from $\mathrm{H}-23$ to C-21, C-22 and $\mathrm{C}-24$ and from $\mathrm{H}-24$ to $\mathrm{C}-21, \mathrm{C}-22$ and $\mathrm{C}-23$. These correlations indicated the connectivity between the indolinone ring and the side chain (from C-20 to C-24). The structure of 1 was determined as shown in Fig. 3 based on all instrumental analyses data. Moreover, using the data of X-ray crystallographic analysis of $\mathbf{1}$ (Fig. 4), the relative configuration of 1 was established as shown in Fig. 1. The crystal data of $\mathbf{1}$ are as follows: Compound formula; $\mathrm{C}_{32} \mathrm{H}_{43} \mathrm{~N}_{3} \mathrm{O}_{6}$. Molecular weight; 565.7. Crystal system; orthorhombic. Space group; $P 22_{1} 2_{1} 2_{1}$. Lattice parameters; $a=14.088 \AA, b=25.809 \AA, c=8.051 \AA, \alpha=90^{\circ}, \beta=90^{\circ}$, $\gamma=90^{\circ}, Z=4, V=2927 \AA^{3}, d=1.28 \mathrm{~g} / \mathrm{cm}^{3}$. Final $R$ and weighted $R$ values were 0.039 and 0.059 , respectively.

The molecular formula of $\mathbf{2}$ was established as $\mathrm{C}_{31} \mathrm{H}_{41} \mathrm{~N}_{3} \mathrm{O}_{6}$ by HR-FAB-MS. The ${ }^{1} \mathrm{H}$ - and ${ }^{13} \mathrm{C}-\mathrm{NMR}$ spectra of $\mathbf{2}$ were similar to those of $\mathbf{1}$ except for the absence of one methylene group at the acyl side chain. The structure of $\mathbf{2}$ was elucidated as shown in Fig. 1.

The molecular formula of $\mathbf{3}$ was established as $\mathrm{C}_{30} \mathrm{H}_{39} \mathrm{~N}_{3} \mathrm{O}_{6}$ by HR-FAB-MS. The ${ }^{1} \mathrm{H}$ - and ${ }^{13} \mathrm{C}-\mathrm{NMR}$ 
Table $2{ }^{1} \mathrm{H}-\mathrm{NMR}(400 \mathrm{MHz})$ and ${ }^{13} \mathrm{C}-\mathrm{NMR}(100 \mathrm{MHz})$ data of $\mathbf{1}, \mathbf{2}$ and $\mathbf{3}$ in $\mathrm{CDCl}_{3}$

\begin{tabular}{|c|c|c|c|c|c|c|}
\hline \multirow{2}{*}{ Position } & \multicolumn{2}{|r|}{1} & \multicolumn{2}{|r|}{2} & \multicolumn{2}{|r|}{3} \\
\hline & $\delta_{\mathrm{C}}{ }^{\mathrm{a})}$ & $\delta_{\mathrm{H}}^{\mathrm{b})}\left(\mathrm{m}^{\mathrm{c})}, J\right.$ in $\left.\mathrm{Hz}\right)$ & $\delta_{\mathrm{C}}^{\text {a) }}$ & $\delta_{\mathrm{H}}^{\mathrm{b})}\left(\mathrm{m}^{\mathrm{c})}, J\right.$ in $\left.\mathrm{Hz}\right)$ & $\delta_{C}^{a)}$ & $\delta_{\mathrm{H}}^{\mathrm{b})}\left(\mathrm{m}^{\mathrm{c})}, J\right.$ in $\left.\mathrm{Hz}\right)$ \\
\hline 1 & & 9.64 (br s) & & 9.65 (br s) & & 9.64 (br s) \\
\hline 2 & $182.1 \mathrm{~s}$ & & $182.1 \mathrm{~s}$ & & $182.1 \mathrm{~s}$ & \\
\hline 3 & $58.7 \mathrm{~s}$ & & $58.7 \mathrm{~s}$ & & $58.7 \mathrm{~s}$ & \\
\hline $3 a$ & $134.5 \mathrm{~s}$ & & $134.5 \mathrm{~s}$ & & $134.5 \mathrm{~s}$ & \\
\hline 4 & $134.2 \mathrm{~d}$ & $7.94(d, 7.6)$ & $134.2 \mathrm{~d}$ & $7.94(d, 7.8)$ & $134.3 d$ & $7.94(d, 7.6)$ \\
\hline 5 & $121.8 d$ & $7.16(t, 7.6)$ & $121.8 d$ & $7.16(t, 7.8)$ & $121.8 d$ & $7.16(t, 7.6)$ \\
\hline 6 & $127.4 \mathrm{~d}$ & $7.76(d, 7.6)$ & $127.4 d$ & $7.76(d, 7.8)$ & $127.4 d$ & $7.76(d, 7.6)$ \\
\hline 7 & $117.2 \mathrm{~s}$ & & $117.2 \mathrm{~s}$ & & $117.2 \mathrm{~s}$ & \\
\hline $7 a$ & $143.0 \mathrm{~s}$ & & $143.0 \mathrm{~s}$ & & $143.0 \mathrm{~s}$ & \\
\hline \multirow[t]{2}{*}{8} & $44.8 \mathrm{t}$ & $1.98(d, 13.4)$ & $44.8 \mathrm{t}$ & $1.97(d, 13.4)$ & $44.7 \mathrm{t}$ & $1.96(d, 13.4)$ \\
\hline & & $2.13(d, 13.4)$ & & $2.13(d, 13.4)$ & & $2.13(d, 13.4)$ \\
\hline 9 & $62.7 \mathrm{~s}$ & & $62.7 \mathrm{~s}$ & & $62.7 \mathrm{~s}$ & \\
\hline \multirow[t]{2}{*}{10} & $56.7 t$ & $2.34(d, 11.2)$ & $56.7 t$ & $2.34(d, 11.2)$ & $56.7 t$ & $2.34(d, 11.0)$ \\
\hline & & $3.01(d, 11.2)$ & & $3.00(d, 11.2)$ & & $3.00(d, 11.0)$ \\
\hline 12 & $53.9 d$ & 3.07 (brt, 6.3) & $53.9 d$ & $3.06(\mathrm{brt}, 6.4)$ & $53.9 d$ & $3.06(b r t, 6.1)$ \\
\hline \multirow[t]{2}{*}{13} & $35.5 t$ & $1.85(\mathrm{~m})$ & $35.4 \mathrm{t}$ & $1.85(\mathrm{~m})$ & $35.3 t$ & $1.88(\mathrm{~m})$ \\
\hline & & $2.00(\mathrm{~m})$ & & $1.99(\mathrm{~m})$ & & $1.98(\mathrm{~m})$ \\
\hline 14 & $68.0 \mathrm{~d}$ & $5.10(\mathrm{brt}, 2.9)$ & $68.2 \mathrm{~d}$ & $5.08(b r t, 2.9)$ & $68.4 \mathrm{~d}$ & $5.07(b r t, 2.9)$ \\
\hline \multirow[t]{2}{*}{15} & $37.8 t$ & $1.50(\mathrm{brt}, 12.9)$ & $37.8 \mathrm{t}$ & $1.50(\mathrm{brt}, 13.0)$ & $37.8 \mathrm{t}$ & $1.50(\mathrm{brt}, 12.7)$ \\
\hline & & $1.85(\mathrm{~m})$ & & $1.85(\mathrm{~m})$ & & $1.88(m)$ \\
\hline 16 & $47.0 \mathrm{~d}$ & 2.79 (brt, 9.8) & $47.0 d$ & $2.81(\mathrm{brt}, 9.3)$ & $47.0 d$ & $2.82(\mathrm{brt}, 9.5)$ \\
\hline \multirow[t]{2}{*}{17} & $30.5 t$ & $1.20(\mathrm{~m})$ & $30.5 t$ & $1.21(\mathrm{~m})$ & $30.5 t$ & $1.21(\mathrm{~m})$ \\
\hline & & $1.67(\mathrm{~m})$ & & $1.66(\mathrm{~m})$ & & $1.67(\mathrm{~m})$ \\
\hline 18 & $50.6 \mathrm{~d}$ & $2.49(\mathrm{dd}, 2.9,13.7)$ & $50.5 d$ & $2.49(\mathrm{dd}, 3.4,13.7)$ & $50.5 d$ & $2.49(\mathrm{dd}, 2.9,13.4)$ \\
\hline 19 & $61.5 \mathrm{~s}$ & & $61.5 \mathrm{~s}$ & & $61.5 \mathrm{~s}$ & \\
\hline 20 & $194.7 \mathrm{~s}$ & & $194.7 \mathrm{~s}$ & & $194.7 \mathrm{~s}$ & \\
\hline 21 & $64.2 \mathrm{~d}$ & 4.05 (s) & $64.2 \mathrm{~d}$ & 4.05 (s) & $64.2 \mathrm{~d}$ & 4.05 (s) \\
\hline 22 & $61.5 \mathrm{~s}$ & & $61.5 \mathrm{~s}$ & & $61.5 \mathrm{~s}$ & \\
\hline 23 & $18.6 \mathrm{q}$ & $1.26(\mathrm{~s})$ & $18.6 \mathrm{q}$ & 1.25 (s) & $18.6 \mathrm{q}$ & $1.26(\mathrm{~s})$ \\
\hline 24 & $24.3 \mathrm{q}$ & 1.61 (s) & $24.3 q$ & $1.60(\mathrm{~s})$ & $24.3 q$ & $1.61(\mathrm{~s})$ \\
\hline 26 & $29.2 \mathrm{q}$ & 2.25 (s) & $29.2 \mathrm{q}$ & $2.25(\mathrm{~s})$ & $29.2 \mathrm{q}$ & 2.25 (s) \\
\hline 27 & $13.2 \mathrm{q}$ & $1.14(d, 6.6)$ & $13.2 \mathrm{q}$ & $1.13(d, 6.8)$ & $13.1 \mathrm{q}$ & $1.14(d, 6.8)$ \\
\hline 28 & $17.9 \mathrm{q}$ & $1.14(\mathrm{~s})$ & $17.9 q$ & 1.15 (s) & $17.9 q$ & $1.14(\mathrm{~s})$ \\
\hline 29 & $201.9 d$ & 9.35 (s) & $201.9 d$ & 9.33 (s) & $201.9 d$ & $9.34(\mathrm{~s})$ \\
\hline $1^{\prime}$ & $173.1 \mathrm{~s}$ & & $173.9 \mathrm{~s}$ & & $170.6 \mathrm{~s}$ & \\
\hline $2^{\prime}$ & $36.8 \mathrm{t}$ & $2.30(\mathrm{dt}, 3.1,7.3)$ & $28.1 \mathrm{t}$ & $2.34(\mathrm{dq}, 2.7,7.6)$ & $21.5 q$ & 2.07 (s) \\
\hline $3^{\prime}$ & $18.4 \mathrm{t}$ & 1.67 (tq, 7.3, 7.3) & $9.1 \mathrm{q}$ & $1.15(t, 7.6)$ & & \\
\hline $4^{\prime}$ & $13.7 q$ & $0.98(t, 7.3)$ & & & & \\
\hline
\end{tabular}

a) $\mathrm{CDCl}_{3}$ was used as the internal standard $\left(\delta_{\mathrm{C}} 77.0 \mathrm{ppm}\right)$.

b) $\mathrm{CHCl}_{3}$ was used as the internal standard $\left(\delta_{\mathrm{H}} 7.26 \mathrm{ppm}\right)$.

c) Multiplicity. 
spectra of $\mathbf{3}$ were similar to those of $\mathbf{1}$ except for the absence of two methylene groups at the acyl side chain. The structure of $\mathbf{3}$ was elucidated as shown in Fig. 1.

\section{Biological Activities}

1, 2 and $\mathbf{3}$ displayed high affinity for both rat and human H3Rs (Table 3). The $K i$ values of rat H3R were $0.058,0.17$ and $0.19 \mu \mathrm{M}$, respectively and the $K i$ values of human H3R were $0.047,0.12$ and $0.22 \mu \mathrm{M}$, respectively. Moreover, these compounds acted as potent agonists with the $\mathrm{EC}_{50}$ values of $0.12,0.15$ and $0.20 \mu \mathrm{M}$, respectively. 1, 2 and 3 did not affect antagonist format (data not shown).

1 did not exhibit antimicrobial activities at $20 \mu \mathrm{g} /$ paper disk.

\section{Discussion}

In the course of our screening for H3R ligands from microorganism, we found three novel compounds, 1, 2 and

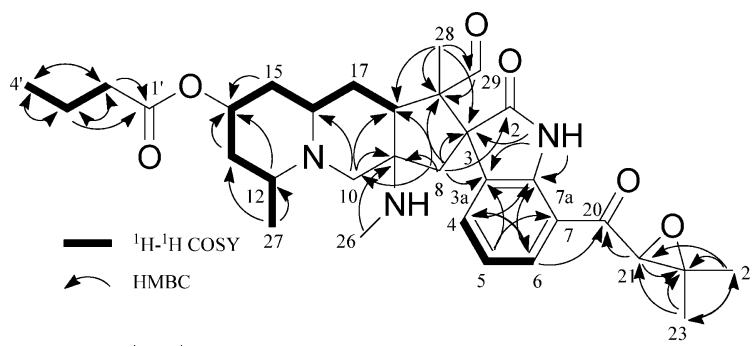

Fig. $3{ }^{1} \mathrm{H}^{1}{ }^{1} \mathrm{H}$ COSY and $\mathrm{HMBC}$ correlations of $\mathbf{1}$.
3 from the culture broth of Penicillium waksmanii PF1270. These compounds possess pentacyclic spiroindolinone skeletons. Several similar structure compounds such as citrinadin A and citrinadin B [16,17] have been isolated from fungi but their stereochemistry at the spiro carbon (C-3) is opposite to that of PF1270s.

Most of the H3R ligands such as $(R)$ - $\alpha$-methylhistamine as an agonist and thioperamide as an antagonist have an imidazole ring that is present in the structure of histamine [18]. However, 1, 2 and $\mathbf{3}$ are novel H3R agonists without an imidazole ring in their molecules. These compounds displayed high affinity for rat H3R and human H3R. Moreover, 1, 2 and $\mathbf{3}$ acted as potent agonists with the $\mathrm{EC}_{50}$ values of $0.12,0.15$ and $0.20 \mu \mathrm{M}$, respectively. The highest affinity of $\mathbf{1}$ toward the H3R may be due to relatively long acyl chain length.

\section{References}

1. Ash AS, Schild HO. Receptors mediating some actions of histamine. Br J Pharmacol Chemother 27: 427-439 (1966)

2. Black JW, Duncan WA, Durant CJ, Ganellin CR, Parsons EM. Definition and antagonism of histamine H2-receptors. Nature 236: 385-390 (1972)

3. Arrang JM, Garbarg M, Schwartz JC. Auto-inhibition of brain histamine release mediated by a novel class (H3) of histamine receptor. Nature 302: 832-837 (1983)

4. Oda T, Morikawa N, Saito Y, Masuho Y, Matsumoto S. Molecular cloning and characterization of a novel type of histamine receptor preferentially expressed in leukocytes. J Biol Chem 275: 36781-36786 (2000)

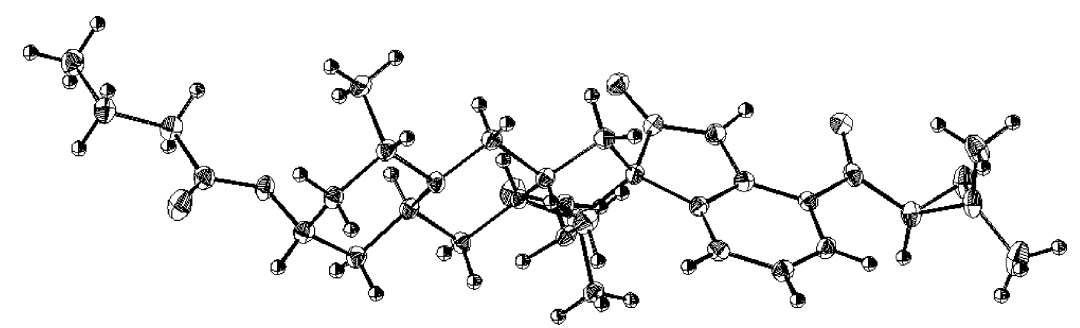

Fig. 4 ORTEP drawing of $\mathbf{1}$.

Table 3 Binding affinity $(K i)$ and potency $\left(E_{50}\right)$ of $\mathbf{1}, \mathbf{2}$ and $\mathbf{3}$ at histamine $\mathrm{H} 3$ receptors

\begin{tabular}{cccc}
\hline Compound & Rat H3R Ki $(\mu \mathrm{M})$ & Human H3R Ki $(\mu \mathrm{M})$ & Human H3R EC ${ }_{50}(\mu \mathrm{M})$ \\
\hline $\mathbf{1}$ & 0.058 & 0.047 & 0.12 \\
$\mathbf{2}$ & 0.17 & 0.12 & 0.15 \\
$\mathbf{3}$ & 0.19 & 0.22 & 0.20 \\
\hline
\end{tabular}


5. Arrang JM, Garbarg M, Schwartz JC. Autoregulation of histamine release in brain by presynaptic H3-receptors. Neuroscience 15: 553-562 (1985)

6. Arrang JM, Garbarg M, Schwartz JC. Autoinhibition of histamine synthesis mediated by presynaptic H3-receptors. Neuroscience 23: 149-157 (1987)

7. Schlicker E, Betz R, Gothert M. Histamine H3 receptormediated inhibition of serotonin release in the rat brain cortex. Naunyn Schmiedebergs Arch Pharmacol 337: 588-590 (1988)

8. Schlicker E, Fink K, Hinterthaner M, Gothert M. Inhibition of noradrenaline release in the rat brain cortex via presynaptic H3 receptors. Naunyn Schmiedebergs Arch Pharmacol 340: 633-638 (1989)

9. Schlicker E, Fink K, Detzner M, Gothert M. Histamine inhibits dopamine release in the mouse striatum via presynaptic H3 receptors. J Neural Transm Gen Sect 93: 1-10 (1993)

10. Yoshimoto R, Miyamoto $\mathrm{Y}$, Shimamura K, Ishihara A, Takahashi K, Kotani H, Airu SC, Howard YC, Douglas JM, Kanatani A, Tokita S. Therapeutic potential of histamine H3 receptor agonist for the treatment of obesity and diabetes mellitus. Proc Natl Acad Sci USA 103: 13866-13871 (2006)

11. Celanire S, Wijtmans M, Talaga P, Leurs R, de Esch IJ. Keynote review: Histamine $\mathrm{H} 3$ receptor antagonists reach out for the clinic. Drug Discov Today 10: 1613-1627 (2005)
12. Perez-Garcia C, Morales L, Cano MV, Sancho I, Alguacil LF. Effects of histamine $\mathrm{H} 3$ receptor ligands in experimental models of anxiety and depression. Psychopharmacology 142: 215-220 (1999)

13. Witkin JM, Nelson DL. Selective histamine H3 receptor antagonists for treatment of cognitive deficiencies and other disorders of the central nervous system. Pharmacol Ther 103: 1-20 (2004)

14. Pitt JI. The genus Penicillium and its teleomorphic states Eupenicillium and Talaromyces. Academic Press, London (1979)

15. Color Harmony Manual. Container Corporation of America (1958)

16. Tsuda M, Kasai Y, Komatsu K, Sone T, Tanaka M, Mikami Y, Kobayashi J. Citrinadin A, a novel pentacyclic alkaloid from marine-derived fungus Penicillium citrinum. Org Lett 6: 3087-3089 (2004)

17. Mugishima T, Tsuda M, Kasai Y, Ishiyama H, Fukushi E, Kawabata J, Watanabe M, Akao K, Kobayashi J. Absolute stereochemistry of citrinadins A and B from marine-derived fungus. J Org Chem 70: 9430-9435 (2005)

18. Arrang JM, Garbarg M, Lancelot JC, Lecomte JM, Pollard H, Robba M, Schunack W, Schwartz JC. Highly potent and selective ligands for histamine H3-receptors. Nature 327: 117-123 (1987) 